\title{
Epilepsy Surgery in Children with Lesional Partial Epilepsies
}

\section{Lezyonel Parsiyel Epilepsili Çocuklarda Epilepsi Cerrahisi}

\author{
Ozdem ERTURK ${ }^{1}$, Cigdem OZKARA ${ }^{1}$, Cengiz YALCINKAYA ${ }^{2}$, Aysin DERVENT ${ }^{2}$, S. Naz YENI ${ }^{1}$, \\ Veysi DEMIRBILEK ${ }^{2}$, Olcay UNVER ${ }^{2}$, Serap UYSAL $^{2}$, Emin OZYURT ${ }^{3}$, Mustafa UZAN $^{3}$ \\ ${ }^{1}$ Istanbul University, Cerrahpasa School of Medicine, Department of Neurology, Istanbul, Turkey \\ ${ }_{2}^{2}$ Istanbul University, Cerrahpasa School of Medicine, Departments of Neurology and Pediatrics, Division of Child Neurology, Istanbul, Turkey \\ ${ }^{3}$ Istanbul University, Cerrahpasa School of Medicine, Department of Neurosurgery, Istanbul, Turkey
}

Corresponding Author: Cigdem OZKARA / E-mail: cigdem.ozkara@gmail.com

\begin{abstract}
AIM: Surgery for epilepsy is a significant treatment alternative with favorable outcomes in the pediatric age group. In this study we present the surgical outcomes of pediatric population referred to our center.

MATERIAL and METHODS: The clinical data of 126 patients ( $\leq 18$ years) with lesional partial epilepsies operated in our center between 19952011 were evaluated retrospectively. Parameters investigated were gender, age at seizure onset, duration of epilepsy, etiology, type and location of operation and outcome. Seizure outcome was classified according to Engel's classification.

RESULTS: The study group consisted of 70 males $(55,6 \%)$ and 56 females (44.4\%). The most common etiology was malformation of cortical development followed by tumors and hippocampal sclerosis. Overall 73.8\% of patients had Engel I, 13.5\% Engel II and 11.9\% Engel III+IV postoperative seizure outcome.

CONCLUSION: The results of our pediatric patients who underwent surgery were similar to previous reports in the literature. The seriousness of the clinical picture should tempt physicians to refer the patients as soon as possible to avoid long term complications like epileptic encephalopathies and the side effects of antiepileptic drugs during the development of the young brains.
\end{abstract}

KEYWORDS: Pediatric epilepsy, Epilepsy surgery, Seizure

öz

AMAÇ: Pediatrik hastalarda epilepsi cerrahisi olumlu sonuçlarıyla önemli bir tedavi seçeneğini oluşturmaktadır. Çalışmada, merkezimizde epilepsi cerrahisi uygulanan pediatrik hastaların cerrahi sonuçlarını sunmayı amaçladık.

YÖNTEM ve GEREÇLER: 1995-2011 yılları arasında merkezimizde lezyonel parsiyel epilepsi tanısıyla opere edilen 126 (yaş $\leq 18$ yıl) hastanın klinik bilgileri retrospektif olarak gözden geçirildi. Değerlendirilen parametreler cinsiyet, nöbet başlangıç yaşı, epilepsi süresi, etiyoloji, ameliyat tipi ve lokalizasyonu ve sonlanımdan oluşuyordu. Nöbet sonlanımları Engel sınıflamasına göre sınıflandı.

BULGULAR: Çalışma grubu $70(\% 55,6)$ erkek ve $56(\% 44,4)$ kızdan oluşmaktaydı. En sık etiyoloji kortikal gelişimsel malformasyonlar iken bunu tümörler ve hipokampal skleroz takip etmekteydi. Tüm hastaların \%73.8'i Engel I, \%13.5'i Engel II ve \%11.9'u Engel III ve IV postoperatif cerrahi sonlanım göstermekteydi.

SONUÇ: Cerrahi uygulanan pediatrik hastalarımızın sonuçları literatürdeki çalışmalar ile benzerlik gösterdi. Klinik tablonun durumuna göre klinisyenlerin hastaları en kısa zamanda cerrahiye yönlendirmeleri epileptik ensefalopatiler gibi uzun dönem komplikasyonlardan ve ilaç yan etkilerinden kaçınmak için önem taşımaktadır.

ANAHTAR SÖZCÜKLER: Pediatrik epilepsi, Epilepsi cerrahisi, Nöbet

\section{INTRODUCTION}

Surgery for epilepsy is a significant treatment alternative with favorable outcomes in the pediatric age group (6). Surgery may be considered if medical intractability is the case or if there is a localized epileptogenic region (12). Etiologic factors for epilepsy surgery differs in children compared with the adults. While the majority of adult epilepsy surgery includes hippocampal sclerosis, it accounts for extratemporal lesions such as malformations of cortical development, tumors or sequel gliosis in children $(6,10,12,13)$. Consequently, extratem- poral/multilobar resections and hemispherectomies are more frequent in this age group contrary to adults (12). Besides preventing the seizures; epilepsy surgery in childhood aims to avoid long term complications like epileptic encephalopathies and the side effects of antiepileptic drugs during the development of the young brains; thus, to avoid possible undesirable neuropsychological outcomes. Therefore it seems important to refer proper candidates for presurgical evaluation without delay. In this study we present and discuss the surgical outcomes of pediatric population referred to our center. 


\section{MATERIAL and METHODS}

The clinical data of 126 patients ( $\leq 18$ years) with lesional partial epilepsies operated in our center between 19952011 were evaluated retrospectively. Patients who had vagal nerve stimulation were not included in the study group. All patients had ictal and interictal video EEG monitoring, cranial MRI for presurgical evaluation. SPECT, PET and fMRI were performed when needed. Neuropsychological testings could not be performed to all patients thus not evaluated in this study. Patients are divided into four age group for further analyses as 0-1, 2-6, 7-12, 13-18 years additionally. Parameters investigated were gender, age at seizure onset, duration of epilepsy, etiology, type and location of operation and outcome. Patients who were followed up at least for one year following surgery were included in the study group. Seizure outcome was classified according to Engel's classification (4).

\section{RESULTS}

The study group consisted of 70 males ( $55.6 \%$ ) and 56 females (44.4\%). Mean age at surgery was $11.5 \pm 4.8$, at seizure onset was $5.1 \pm 4.3$ years. Out of 126 patients $45.2 \%$ had daily seizures, $34.9 \%$ had seizures $1-6 /$ week, $14.3 \%$ had $1-4$ /month and $5.6 \%$ had less than a seizure for a month. At the time of the surgery $45.2 \%$ of patients was on three or more , $38.1 \%$ was on two and $16.7 \%$ was on one type of antiepileptic drug. Mean duration of epilepsy from diagnosis to surgery was $6.4 \pm 4.6$ years the highest group being 13-18 yr age group with a mean of 8.5 years. Mean follow up was $5.8 \pm 3.7$ years (1-17). The data according to age groups is summarized at Table I.

Overall the most common etiology was malformations of cortical development (MCD) dominated by focal cortical dysplasias type I (11 patients) and type II (28 patients) additionally a few patients with polymicrogyria, pachygyria, schizencephaly; followed by tumors and hippocampal sclerosis (HS). The most common etiology for 13-18 yr age group was hippocampal sclerosis, whereas it was MCD for 7-12 yr and tumors for 2-6 yr age group (Table I). Most common tumor was DNET (39.3\%) followed by gangliogliomas (35.7\%) where oligodendrogliomas constituted $7.1 \%$ of the them.

Thirty-two patients underwent intracranial recordings before surgery ( 14 subdural, 13 depth and 5 both).

Most of the patients had temporal (46\%), remaining had extratemporal and multilobar resections (42.9\%), and a minority underwent hemispherectomy (4.8\%) and callosotomy (5.6\%). While the majority of temporal resections includes patient over 12, extratemporal and multilobar resections and hemispherectomies were more frequently performed for patients under 12. Overall $73.8 \%$ of patients had Engel I, $13.5 \%$ Engel II and $11.9 \%$ Engel III+IV postoperative seizure outcome. One patient died at 3th month postoperatively possibly due to SUDEP. Eight patients had different degrees of hemiparesis as surgical complication.
Overall $73.8 \%$ of patients had Engel I outcome. This incidence was lower for MCD (65.1\%). Patients with HS had better results where majority achieved seizure freedom (87.5\%) without any patients in class III or IV. Contrary to these results, gliotic lesions which were either vascular, traumatic or due to an undetermined cause showed a relatively high percentage of unfavorable outcome ( $15.4 \%$ in class III and IV) comparing with $\mathrm{HS}$ and tumors.

When we compare outcomes according to ages, older age groups had higher seizure freedom rates than patients under 7 years. This may be due to difference of the etiologies.

Outcome according to age, pathology and surgery is summarized at Table II.

\section{DISCUSSION}

The aim of our study was to report surgical results of pediatric epilepsy patients who underwent surgery in our center.

In our study group the most common etiology was MCD as previously reported elsewhere $(3,6,10,12)$. Other most common etiologies were tumors, HS and gliosis. MCD and tumors predominate under 12 years but in patients over 12 years $\mathrm{HS}$ is more commonly observed, likewise in other series (10). Five patients had both MCD and HS in pathological specimens which are classified as dual pathology. In 4 of them both lesions were in the same temporal lobe, 3 of them having focal cortical dysplasia (FCD) type I and II B and remained seizure free after surgery where the 4th with a large porencephalic cavity extending from occipital to temporal lobe has still seizures. In the fifth patient the pathologies were localized to two different lobes at the right side with cortical dysplasia type IIB at the frontal lobe in addition to HS. This patient underwent both frontal lesionectomy and anterior temporal resection in the same intervention after being evaluated with subdural electrodes which revealed early involvement of cortical dysplasia during the ictal episode and concluded with complete seizure freedom for 8 years.

The lower incidence of complete seizure freedom in patients with MCD which is consistent with previous reports may be related to incomplete resection of the epiletogenic zone as proposed in previous reports (7). The lesions at temporal lobe have a tendency for better seizure freedom rates. A recent meta analysis reported that, in addition to a temporal lobe location, partial seizures, detection with MRI and a Type II histopathology, complete resection of the anatomical or electrographic abnormality were the most important predictors of overall seizure freedom of FCD (9).

Resection of tumors have better outcomes than of MCD's. The tumor location was more common in the temporal lobes compared to extratemporal and the seizure freedom rate as high as $85.1 \%$ similar to previous reports $(5,10)$.

When outcome results were analysed according to the localization temporal lobe resections were found to be the most common which was performed for HS, followed by MCD and tumoral lesions. The second most commonly encountered 
Table I: Age at Onset, Surgery, Duration and Etiology according to Age Groups

\begin{tabular}{|c|c|c|c|c|c|}
\hline Age (years) & $13-18 \mathrm{yr}$ & $7-12$ yr & $2-6 \mathrm{yr}$ & $0-1$ yr & Total \\
\hline Number & 63 & 43 & 15 & 5 & 126 \\
\hline $\begin{array}{l}\text { Age at seizure onset } \\
\text { Age at surgery }\end{array}$ & $\begin{array}{c}6.9 \pm 4.6 \\
15.4 \pm 1.7\end{array}$ & $\begin{array}{l}4.1 \pm 3.2 \\
9.7 \pm 1.7\end{array}$ & $\begin{array}{l}1.9 \pm 1.8 \\
4.0 \pm 1.6\end{array}$ & $\begin{array}{c}0.1 \\
0.5 \pm 0.3\end{array}$ & $\begin{array}{c}5.1 \pm 4.3 \\
11.5 \pm 4.8\end{array}$ \\
\hline Duration of epilepsy(years) & $8.5 \pm 4.8$ & $5.5 \pm 3.1$ & $2.1 \pm 1.6$ & $0.4 \pm 0.3$ & $6.4 \pm 4.6$ \\
\hline \multicolumn{6}{|l|}{ Etiology, number } \\
\hline MCD & 15 & 19 & 5 & 4 & 43 \\
\hline HS & 20 & 4 & - & - & 24 \\
\hline Tumor & 12 & 10 & 6 & - & 28 \\
\hline Gliosis & 5 & 7 & 1 & - & 13 \\
\hline Neurocutaneous syndromes* & 2 & - & 2 & - & 4 \\
\hline Dual pathology & 4 & 1 & - & - & 5 \\
\hline Rasmussen & 2 & - & - & - & 2 \\
\hline Vascular & 1 & 1 & 1 & - & 3 \\
\hline $\mathrm{LGS}^{* *}$ & - & 1 & - & - & 1 \\
\hline Hemimegalencephaly & - & - & - & 1 & 1 \\
\hline Miscellaneaus & 2 & - & - & - & 2 \\
\hline
\end{tabular}

*Sturge Weber syndrome+Tuberous sclerosis

**Lennox-Gastaut syndrome

Table II: Age, Pathology and Surgery Related to Outcome

\begin{tabular}{|c|c|c|c|c|c|}
\hline Age & $\mathbf{n}$ & $\%$ & Engel I (\%) & Engel II (\%) & Engel III+IV (\%) \\
\hline $13-18$ & 63 & 50 & 74.6 & 15.9 & 9.5 \\
\hline $7-12$ & 43 & 34.1 & 74.4 & 11.6 & 13.9 \\
\hline $2-6$ & 15 & 11.9 & 66.7 & 13.4 & 20 \\
\hline $0-1$ & 5 & 3.9 & 60 & 40 & - \\
\hline \multicolumn{6}{|l|}{ Pathology } \\
\hline MCD & 43 & 34.1 & 65.1 & 16.3 & 16.3 \\
\hline $\mathrm{HS}$ & 24 & 19.1 & 87.5 & 12.5 & - \\
\hline Tumor & 28 & 22.2 & 82.1 & 10.7 & 7.1 \\
\hline Gliosis & 13 & 10.3 & 76.9 & 7.7 & 15.4 \\
\hline \multicolumn{6}{|l|}{ Surgery } \\
\hline Temporal resection & 58 & 46.0 & 82.8 & 10.3 & 6.9 \\
\hline Extratemporal resection & 54 & 42.9 & 73.6 & 13.2 & 13.2 \\
\hline Frontal & 25 & 19.8 & & & \\
\hline Parietal & 11 & 8.7 & & & \\
\hline Occipital & 11 & 1.6 & & & \\
\hline Multilobar & 16 & 12.7 & & & \\
\hline Hypothalamic & 1 & 0.8 & & & \\
\hline Hemispherectomy & 6 & 4.8 & 83.3 & 16.7 & - \\
\hline Callosotomy & 7 & 5.6 & 14.3 & 28.6 & 57.1 \\
\hline
\end{tabular}


resection was frontal followed by multilobar resections. The majority of the patients who underwent temporal resection had a favorable outcome (Engel I 82.8\%) which is consistent with the literature $(6,13)$. Extratemporal resections comprising $42.9 \%$ of the patients showed less successful results when compared with temporal lobe resections but more than $70 \%$ of patients achieved seizure freedom. Surgery for temporal regions have been reported to be associated with better outcomes in other series including pediatric patients. A similar study reports $73 \%$ Engel I outcome for temporal resections, $64 \%$ for extratemporal resections (11).

Hemisferectomy was applied to 6 children. The etiologies were gliotic lesions, Rasmussen encephalitis, SWS, hemimegalencphaly and FCD. All had favorable outcomes (Engel class I \& II) without any complications after surgery. A recent study that evaluated the results of hemispherectomies in 45 pediatric patients also reported $73.5 \%$ Engel I outcomes (1).

Although timing of surgery is reported to be as long as 10 years after the onset of seizures for patients older than 12 years, this time is shorter for patients younger than this age (10). This may be due to relatively lower frequency of seizures in older patients which was shown in our results as well. Timing of surgery was between 2-5 years after the onset of seizures for children below 12 years, however it was much longer (mean $8.5 \pm 4.8$ ) for children above 12 years. The frequencies of the seizures differed between age groups and daily seizures occurred in almost $60 \%$ of younger but about only $30 \%$ of older patients, which was partially similar to previous reports $(10,12)$. Apparently a delay in referral to a surgical center is a general problem in many countries.

Continuous discharges in EEG are known to be related to cognitive impairment during childhood. In 5 of our patients, EEG revealed generalized spike and wave discharges, which was diagnosed to be electrical status epilepticus during sleep (ESES) in one patient with polymicrogyri at frontal lobe. In addition to termination of her seizures after surgery, her cognitive functions markedly improved which is concordant with the beneficial effects of surgery on ESES in the literature (8). Behavioral improvement after surgery was observed in another patient who was suffering from seizures due to ischemic gliotic lesions, supporting the beneficial effects of early surgery on behavioral as well as cognitive development in childhood. In two patients with the clinical features of encephalopathy, the lesions were unilateral diffuse cortical dysplasia and gliosis and the EEG was not contributory to localize the epileptogenic zone with bilateral epileptiform discharges. Both of these patients were seizure free after hemispherectomy, the surgical procedure which has been reported to be useful in patients with bilateral findings related to a structural lesion in one hemisphere (1).

The results of our pediatric patients who underwent surgery were similar to previous reports in the literature. Although the first aim of epilepsy surgery is seizure control, improvement of the neuropsychological and behavioral outcome of the child after seizure control is also an important aspect of epilepsy surgery (2). Although the outcomes after epilepsy surgery are more or less similar in children compared to adult patients, the timing of surgery in the pediatric population is much more critical than adults. The seriousness of the clinical picture should tempt physicians to refer the patients as soon as possible to avoid long term complications like epileptic encephalopathies and the side effects of antiepileptic drugs during the development of the young brains.

\section{ACKNOWLEDGMENTS}

We would like to thank Gulsum Akdeniz for her help by collecting the data.

\section{REFERENCES}

1. Caraballo R, Bartuluchi M, Cersósimo R, Soraru A, Pomata H: Hemispherectomy in pediatric patients with epilepsy:a study of 45 cases with special emphasis on epileptic syndromes. Childs Nerv Syst 27:2131-2136, 2011

2. Cross JH, Jayakar P, Nordli D, Delalande O, Duchowny M, Wieser HG, Guerrini R, Mathern GW; International League against Epilepsy, Subcommission for Paediatric Epilepsy Surgery; Commissions of Neurosurgery and Paediatrics Proposed criteria for referral and evaluation of children for epilepsy surgery: Recommendations of the Subcommission for Pediatric Epilepsy Surgery. Epilepsia 47:952-959, 2006

3. Dunkley C, Kung J, Scott RC, Nicolaides P, Neville B, Aylett SE, Harkness W, Cross JH: Epilepsy surgery in children under 3 years. Epilepsy Res 93:96-106, 2011

4. Engel J Jr, Van Ness PC, Rasmussen TB, Ojemann LM: Outcome with respect to epileptic seizures. In: Engel J Jr (ed). Surgical treatment of the epilepsies. New York: Raven Press, 1993: 609621

5. García-Fernández M, Fournier-Del Castillo $C$, Ugalde-Canitrot A, Pérez-Jiménez Á, Álvarez-Linera J, De Prada-Vicente I, Suárez-Rodríguez J, Bernabeu-Verdú J,Villarejo-Ortega F: Epilepsy surgery in children with developmental tumours. Seizure 20:616-627, 2011

6. Hemb M, Velasco TR, Parnes MS, Wu JY, Lerner JT, Matsumoto JH, Yudovin S, Shields WD, Sankar R, Salamon N, Vinters HV, Mathern GW: Improved outcomes in pediatric epilepsy surgery: The UCLA experience, 1986-2008. Neurology 74:1768-1775, 2010

7. Krsek P, Maton B, Jayakar P, Dean P, Korman B, Rey G, Dunoyer C, Pacheco-Jacome E, Morrison G, Ragheb J, Vinters HV, Resnick T, Duchowny M: Incomplete resection of focal cortical dysplasia is the main predictor of poor postsurgical outcome. Neurology 72:217-223, 2009

8. Loddenkemper T, Cosmo G, Kotagal P, Haut J, Klaas P, Gupta A, Lachhwani DK, Bingaman W, Wyllie E: Epilepsy surgery in children with electrical status epilepticus in sleep. Neurosurgery 64:328-337, 2009 
9. Rowland NC, Englot DJ, Cage TA, Sughrue ME, Barbaro NM, Chang EF: A meta-analysis of predictors of seizure freedom in the surgical management of focal cortical dysplasia. J Neurosurg 116:1035-1041, 2012

10. Terra-Bustamante VC, Fernandes RM, Inuzuka LM, Velasco TR, Alexandre V Jr, Wichert-Ana L, Funayama S, Garzon E, Santos AC, Araujo D, Walz R, Assirati JA, Machado HR, Sakamoto AC: Surgically amenable epilepsies in children and adolescents: Clinical, imaging, electrophysiological, and post-surgical outcome data. Childs Nerv Syst 21:546-551, 2005
11. Van Oijen $M$, De Waal $H$, Van Rijen PC, Jennekens-Schinkel A, van Huffelen AC, Van Nieuwenhuizen O; Dutch Collaborative Epilepsy Surgery Program Resective epilepsy surgery in childhood: The Dutch experience 1992-2002. Eur J Paediatr Neurol 10:114-123, 2006

12. Wyllie E: Surgical treatment of epilepsy in pediatric patients. Can J Neurol Sci 27:106-110, 2000

13. Wyllie E, Comair YG, Kotagal P, Bulacio J, Bingaman W, Ruggieri $P$ : Seizure outcome after epilepsy surgery in children and adolescents. Ann Neurol 44:740-748, 1998 